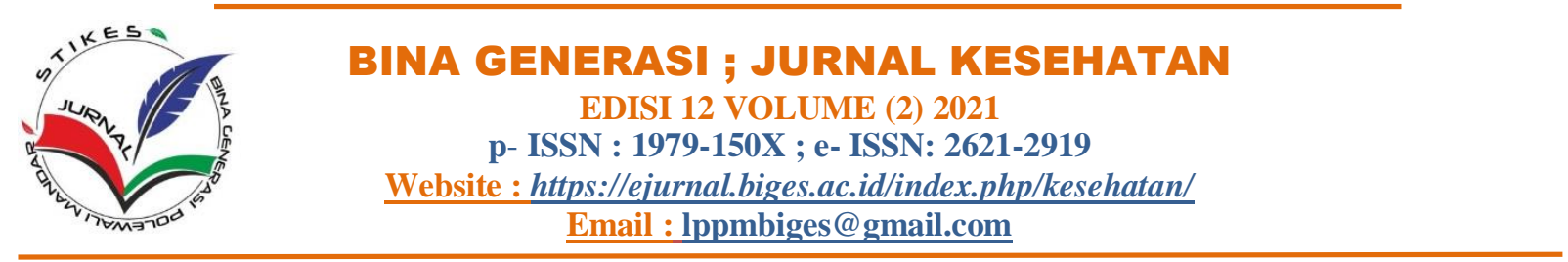

\title{
KONSELING PADA IBU YANG MEMILIKI BALITA GIZI KURANG
}

\author{
Darmiati $^{1}$, Fredy Akbar K ${ }^{2}$, Andi Jiwi Aco Syamsi ${ }^{3}$ \\ 1,2,3 Program Studi Akademi Keperawatan Yppp wonomulyo \\ ajiwi28111998@gmail.com
}

Keywords:

Toddles;

Malnutrition;

Counseling

\begin{abstract}
Toddler period is a golden age because of rapid growth and development gross motor and fine motor development of the child, and currently the main health problem in Indonesia is nutrition. Polewali District Health Office Mandar reported in 2014 the prevalence of under-five nutrition in Polewali Mandar Regency namely malnutrition 153 (0.37\%), deficient nutrition 1,250 (3.44\%), malnutrition 204 (0.57\%), BGM 870 (2.44\%). The problems found in Rumpa Village included interviews mothers of toddlers showed that the number of under-fives was 35, one of the appropriate interventions to overcome this problem is by increasing it Mother's knowledge because mother is the main factor affecting toddler nutrition. Efforts to increase maternal knowledge can be done through counseling with the counseling method. This research is a quantitative study with a cross cost design. Research conducted in Rumpa Village and Buku Village, Mapilli District, Polewali Mandar Regency, West Sulawesi Province. The research time starts on 27 July - 5 September 2020. With respondents as many as 70 people who were divided into 2 groups with each group of 35 people. The results showed that there were significant differences in initial knowledge and after extension using the counseling method ( $p$ value $=0.000$ ) was found differences in maternal knowledge about the prevention of malnutrition among mothers of children under five in offering counseling method p value 0.000. Closing counseling with indepth counseling methods increase the knowledge of mothers about the prevention of malnutrition, officers In conducting extension, permission uses extension methods. researchers can extend the treatment method to other methods.
\end{abstract}

\section{PENDAHULUAN}

Masa balita adalah masa yang menitikberatkan pada pentingnya perhatian peningkatan pertumbuhan dan perkembangan. Masa balita adalah masa emas ( golden age periode) karna cepatnya pertumbuhan dan perkembangan fisik motorik kasar dan motorik halus anak tersebut (Elizabeth,2006). Seiring dengan proses belajarnya Maka anak banyak bergerak dan melakukan eksplorasi untuk memenuhi rasa ingin taunya, Anak akan berjalan, berlari, bermain, dan bernyanyi, bahkan berfikir. Berat otak anak kurang dari 10 $\%$ dari total berat tubuhnya, namun kebutuhan energinya lebih dari $40 \%$ total energy tubuh untuk mendukung pertumbuhan dan perkembangan otaknya (Khasanah, 2014) Berdasarkan data WHO memperkirakan bahwa 54\% kematian anak disebabkan oleh keadaan gizi yang buruk. Sementara masalah gizi di Indonesia mengakibatkan lebih dari $80 \%$ kematian anak. Jumlah penderita kurang gizi di 
dunia mencapai 104 juta anak di bawa usia 5 tahun, dan keadaan kurang gizi menjadi penyebab sepertiga dari seluruh penyebab kematian anak di seluruh dunia. Sedangkan pada tahun 2013, WHO melaporkan bahwa 99 juta anak dibawa usia 5 tahun menderita kurang gizi di diantaranya $67 \%$ terdapat di Asia dan 29\% di Afrika3 (Rahayu, 2018).

Saat ini kesehatan masyarakat yang utama di indonesia adalah masalah gizi dimana tubuh mengalami gangguan dalam zat gizi untuk pertumbuhan,perkembangan dan aktivitas (Khasanah, 2014) ' Dampak kekurangan gizi bukan hanya menimbulkan masalah kesehatan saja namun juga menurunkan kualitas Sumber Daya Manusia (SDM) yang sangat diperlukan di masa yang akan datang. Risiko kematian anak gizi buruk 17 kali lipat dibandingkan dengan anak normal. Oleh karena itu, setiap anak gizi buruk harus dirawat sesuai standar yang diperlukan dalam penanganan gizi (Rahmawati, 2017). Proses untuk menjadikan seorang anak mengalami kegagalan pertumbuhan dimulai pada saat didalam rahing hingga usia dua tahun. Proses tersebut dipengaruhi oleh asupan dan praktik pemberian makan yang diberikan. Hal tersebut terjadi karena seringkali ibu tidak memiliki pengetahuan tentang gizi dan perilaku kesehatan(Kesehatan, 2013)

Dinas kesehatan kabupaten polewali mandar melaporkan tahun 2014 prevalensi keadaan gizi balita di kabupaten polewali mandar yaitu gizi buruk $153(0,37 \%)$, gizi kurang $1.250(3,44 \%)$, gizi lebih $204(0,57 \%)$, BGM 870 (2,44\%) (Dinkes polman,2014). Salah satu upaya pemerintah dalam menanggulangi gizi kurang dan gizi buruk pada balita yaitu dengan mencanangkan aksi dalam mencegah,menanggulangi gizi kurang dan gizi buruk yang merupakan prioritas pada rencana pembangunan jangka menengah daerah (RPJMD) dan upaya meningkatkan cakupan deteksi dini gizi kurang dan gizi buruk melalui penimbangan bulanan balita di posyandu, meningkatkan cakupan dan kualitas tatalaksanaan status gizi buruk dipuskesmas, rumah sakit dan rumah tangga dan untuk meningkatkan pengetahuan ibu dalam pemberian asupan gizi pada balita (ASI/MPASI), (K, 2019)

Masalah gizi kurang,terjadi karena banyaknya factor yang saling mempengaruhi ditingkat keluarga, (Yusuf, 2012)Pengetahuan sikap dan praktik ibu tentang kesehatan menentukan bahwa status gizi balita dipengaruhi secara signifikan oleh pengetahuan yang dimiliki ibu. sikap dan perilaku gizi ibu. Sejalan dengan penelitian (Kusumaningrum, et al.2018) yaitu konseling gizi seimbang 4 minggu 4 kali pertemuan memberikan pengaruh yang singnifikan terhadap pengetahuan gizi ibu serta pola makan gizi kurang pada bahan makanan sayur,buah,dan laut hewani. Kurangnya peran aktif ibu untuk mencari informasi dalam pemenuhan kebutuhan asupan nutrisi balita,dan tidak menutup ke mungkinan akan berdampak buruk pada pemberian asupan nutrisi pada balita sehingga akan mengganggu proses pertumbuhan dan tidak tercukupinya asupan nutrisi dengan baik yang mengakibatkan balita mengalami gangguan nutrisi.

Konseling adalah kegiatan Pendidikan yang dilakukan dengan cara menyebarkan pesan, menanamkan keyakinan, sehingga masyarakat tidak saja sadar, tahu dan mengerti. Tetapi juga mau dan bisa melakukan suatu anjuran yang ada hubungannya dengan kesehatan. Konseling gizi adalah kegiatan pemberian informasi atau nasehat gizi dan dietik yang erat kaitannya dengan kondisi gizi dan kesehatan seseorang, konseling gizi terlebih dahulu diawali dengan pengkajian gizi ( depkes RI 2012) kurangnya gizi pada balita juga disebabkan perilaku ibu dalam pemilihan bahan makanan, tersedianya jumlah makanan yang cukup dan keanekaragaman makanan ini dipengaruhi oleh tingkat pengetahuan ibu tentang makanan dan gizinya. Ketidak tahuan ibu dapat menyebabkan kesalahan pemilihan makanan terutama untuk balita (Purba, lili sari A. and Harahap, 2019) konseling gizi merupakan suatu proses komunikasi dua arah antar konselor dan klien untuk membantu klien mengenali dan mengatahui masalah gizi (perbedaan pengetahuan ibu tentang pencegahan gizi kurang antara metode konseling dengan leflet di puskesmas bengkunut, kabupaten pesisir barat ). Peningkatan pengetahuan juga dipengaruhi oleh tahapan konseling yaitu materi diberikan bertahap dengan pengulangan pada pertemuan berikutnya. Pengetahuan baik tentang gizi akan membantu ibu dalam memilih bahan makanan dan pemberian asupan bagi anak.

Dengan demikian kebutuhan tubuh anak akan zat gizi tercukupi. Peningkatan 
pengetahuan gizi akan mempengaruhi praktik ibu dalam pemilihan, pengolahan dan pemberian makan anak sehingga meningkatkan status gizi kearah yang lebih baik.(Kusumaningrum \& Pudjirahaju, 2018) . Sejalan dengan hasil penelitian (Rahayu, 2018a) menunjukkan ada pengaruh gizi terhadap pengetahuan gizi pada kelompok perlakuan diwilaya kerja puskesmas Rapak Mahang Tenggarong dengan nilai $p$ value $(0,000)<0,05$. Dan ada pengaruh konseling gizi terhadap pola asuh pada kelompok perlakuan diwilaya kerja puskesmas Rapak Mahang Tenggarong dengan nilai $\mathrm{p}$ value ( $0,000)<0.05$ pada kelompok kontrol hasil uji statistik didapatkan $\mathrm{p}$ value sebesar (0.229) > 0,05 , hal ini berarti tidak ada berbedaan pengetahuan pada awal penelitian dan akhir penelitian. Sedangkan pada kelompok kontrol, hasil uji statistik didapatkan $\mathrm{p}$ value sebesar $(0,038)<0,05$ berarti ada perbedaan pola asuh pada awal pengukuran dan akhir pengukuran.

Balita gizi kurang akan rentan sekali terhadap berbagai penyakit, kondisi gizi kurang akan banyak mempengaruhi organ dan sistemnya karna sering disertai defisiensi asupan gizi mikro dan makro yang sangat diperlukan bagi tubuh,kondisi kurang gizi yang tidak ditangani akan berdampak buruk terhadap gangguan pertumbuhan dan perkembangan balita baik itu secara fisik maupun mental yang akan berdampak dalam jangka panjang,maka diperlukan pengetahuan ibu untuk memperhatikan kandungan dalam makanan, pengaruh metabolik, dan sifat-sifat yang terkandung dalam makanan serta pengaruh metabolik bila terdapat kekurangan atau kelebihan gizi (Puspitasari, 2015) untuk menghindari terjadinya loss generation salah satu cara yang dilakukan dalam membantu meningkatkan kesadaran dan pengetahuan gizi ibu adalah dengan melakukan kegiatan konseling agar pengetahuan ibu dapat meningkat dalam pemberian makanan bagi balita (Yusuf, 2012)

\section{METODE}

Penelitian ini merupakan penelitian penelitian kuantitatif dengan desain cross costional menggunakan uji chi square. yang digunakan karena peneliti mengelompokkan anggota sampel secara tidak acak dan dibagi kedalam dua kelompok dengan perlakuan yang berbeda yaitu kelompok perlakuan dan kelompok kontrol.

Pengacakan tidak dapat dilakukan karena sampel yang di teliti sebaiknya homogen berdasarkan lokasi tempat tinggalnya. Konseling gizi diberikan 4 minggu dengan 4 kali pertemuan. Penelitian dilakukan di Desa Rumpa dan Desa Buku, Kecamatan Mapilli, Kabupaten Polewali Mandar, Provinsi Sulawesi Barat. Waktu penelitian dimulai pada bulan 27 juli sampai 5 september 2020. Sampel penelitian ialah balita $<5$ tahun dengan status gizi kurang, sedangkan untuk responden adalah ibu dari balita tersebut. Penelitian dibagi menjadi dua kelompok, kelompok perlakuan mendapat pemberian bimbingan konseling pada ibu balita untuk penurunan gizi kurang. Sedangkan, untuk kelompok kontrol tidak mendapatkan intervensi pemberian konseling. Dengan diberikan sebuah koesioner penelitian untuk membandingkan antara dua kelompok. Jumlah responden sebanyak 70 orang yang dibagi dalam 2 kelompok dengan masingmasing kelompok berjumlah 35 orang.

Adapun Tahap pengumpulan / penelitian yaitu Mempersiapkan alat maupun bahan yang akan digunakan dalam menunjang hasil observasi yang lengkap, Menetapkan jumlah sampel serta populasi berdasarkan usia, Setelah itu dilakukan penimbangan dan pengukuran tinggi balita, Kemudian lakukan intervensi pada kelompok perlakuan yaitu memberikan konseling, sedangkan untuk kelompok kontrol tidak diberikan intervensi seperti kelompok perlakuan, Setelah dianalisis selama satu bulan simpulkan hasil yang telah didapatkan dari hasil perbandingan dua kelompok, serta perubahan yang terjadi pada kelompok perlakuan. Penelitian dilakukan dengan pengukuran dan pengamatan yang dilakukan dengan krtiteria inklusinya yakni balita.Jumlah responden sebanyak 70 orang yang dengan masing-masing kelompok berjumlah 35 orang. 
HASIL

Karakteristik Ibu Balita Di Desa Rumpa dan Desa Buku Kabupaten Polewali Mandar.

\begin{tabular}{ccc}
\hline Variabel & Frekuensi & Persentasi \\
\hline & Umur \\
20-29 tahun & 34 orang & $45,4 \%$ \\
$30-45$ tahun & 36 orang & $54,6 \%$ \\
\hline & Pendidikan \\
TS & 5 orang & $8,0 \%$ \\
SD & 35 orang & $42,5 \%$ \\
SMP & 13 orang & $20,1 \%$ \\
SMA & 11 orang & $18,5 \%$ \\
Diploma & 2 orang & $4,5 \%$ \\
Sarjana & 4 orang & $7,2 \%$ \\
\hline Pekerjaan & & \\
IRT & 62 orang & $70,5 \%$ \\
Swasta & 3 orang & $10,2 \%$ \\
PNS & 1 orang & 9,0 \\
Honorer & 4 orang & $10,3 \%$ \\
\hline Total & 70 orang & $100 \%$ \\
\hline
\end{tabular}

Berdasarkan tabel 1, karakteristik responden didesa Rumpa dan Buku terdiri dari umur ibu yang memiliki balita gizi kurang paling banyak pada kategori 30-45 tahun $(54,6 \%)$. Kemudian dari karakteristik pendidikan terakhir ibu didapatkan Pendidikan ibu yang paling banyak ialah SD (42,5\%). Dan karakteristik dari pekerjaan ibu paling banyak adalah ibu rumah tangga (IRT) sebanyak 70,55\%

\section{Tabel 2. Hasil Analisis pada kelompok Perlakuan dan Kontrol}

\begin{tabular}{|c|c|c|c|c|c|c|c|c|c|}
\hline Kategori & & Kelom! & k perl & akuan & & Kelo & ompok & ontro & \\
\hline Konseling & & e-Test & & $\overline{\text { st-Test }}$ & & Pre-1 & Test & Pos & \\
\hline & $n$ & $\%$ & $n$ & $\%$ & $n$ & $\%$ & $n$ & $\%$ & \\
\hline Paham & 10 & 32,6 & 14 & 39,6 & 14 & 36,4 & 1 & 36 & \\
\hline Tidak Paham & 25 & 67,4 & 21 & 60,4 & & 21 & 63,6 & & 63,6 \\
\hline Total & 35 & 100 & 35 & 100 & & 35 & 100 & 35 & 100 \\
\hline Rata-Rata & &, 60 & &, 65 & & $\mathbf{0 , 3 7}$ & & & 9 \\
\hline
\end{tabular}

Tabel 3. Hasil rata-rata pada kelompok Perlakuan dan Kontrol

\begin{tabular}{|c|c|c|c|c|c|}
\hline \multirow{3}{*}{$\begin{array}{l}\text { Kelompok } \\
\text { perlakuan }\end{array}$} & \multicolumn{4}{|c|}{ POLA ASUH } & \multirow{3}{*}{$\mathrm{p}$ value } \\
\hline & \multicolumn{2}{|c|}{ Sebelum } & \multicolumn{2}{|c|}{ Sesudah } & \\
\hline & $\mathbf{N}$ & $\%$ & $\mathbf{N}$ & $\%$ & \\
\hline paham & 10 & 32,6 & 14 & 39,6 & \\
\hline tidak paham & 25 & 67,4 & 21 & 60,4 & 0,000 \\
\hline total & 35 & 100 & 35 & 100 & \\
\hline rata-rata & 0,37 & & 0,9 & & \\
\hline
\end{tabular}




\begin{tabular}{|c|c|c|c|c|c|}
\hline \multirow{3}{*}{$\begin{array}{l}\text { Kelompok } \\
\text { kontrol }\end{array}$} & \multicolumn{4}{|c|}{ POLA ASUH } & \multirow{3}{*}{$\mathrm{p}$ value } \\
\hline & \multicolumn{2}{|c|}{ Sebelum } & \multicolumn{2}{|c|}{ Sesudah } & \\
\hline & n & $\%$ & $\mathbf{N}$ & $\%$ & \\
\hline paham & 14 & 36,4 & 14 & 36,4 & \\
\hline tidak paham & 21 & 36,6 & 21 & 36,6 & - \\
\hline total & 35 & 100 & 35 & 100 & \\
\hline rata-rata & 0,37 & & 0,9 & & \\
\hline
\end{tabular}

\section{PEMBAHASAN}

Hasil pre-test dan post-test konseling pada kelompok perlakuan menunjukkan terjadinya sedikit peningkatan. Hasil post-test terhadap pemahaman pola asuh ibu balita, pada kelompok perlakuan terjadi peningkatan dari 10 responden $(32,6 \%)$ pada saat pre-test menjadi 10 responden $(39,6 \%)$ pada saat post-test sedangkan sisanya 21 responden $(60,4 \%)$ masih belum memahami tentang pola asuh ibu balita. Sedangkan presentasi pada kelompok kontrol menunjukkan tidak terjadi peningkatan hasil post-test namun justru menurun. Hasil pre-test pada konseling dengan pemahaman pola asuh dengan kelompok kontrol menunjukkan sebanyak 14 responden $(39,6 \%)$ dan turun menjadi 8 responden $(25,5 \%)$ pada saat posttest.

Juga penelitian dari (Nugraha, 2017) mengatakan bahwa umur sebagaian besar responden, yaitu 25 orang $(83,3 \%)$ berumur antara 20-30 tahun. Berdasarkan tingkat pekerjaan ibu balita gizi kurang semuanya sebagai ibu rumah tangga (IRT). Berdasarkan tingkat pendidikan ibu balita sebagian besar berpendidikan tamat SMP 18 0rang (60,0\%). Berdasarkan pembagian kelompok umur balita gizi kurang dibagi 3 kelompok umur, yakni 6-9 bulan sebanyak 6 orang $(20,0 \%), 9-12$ bulan sebanyak 4 orang $(13,3 \%)$ dan $12-24$ bulan sebanyak 20 orang $(66,7 \%)$. Berdasarkan jenis kelamin balita sebagian besar berjenis kelamin laki - laki 18 orang (60,0\%). Berdasarkan tindakan ibu dalam pemberian MP-ASI pada kelompok perlakuan yang diberikan konseling gizi terjadi perubahan tindakan ibu, dimana sebelum konseling gizi tindakan ibu dalam kategori baik terdapat 1 orang $(6,7 \%)$. Meningkat setelah dilakukan intervensi mencapai 15 orang $(100,0 \%)$. Berdasarkan nilai rerata berat badan balita gizi kurang pada kelompok perlakuan sebelum dan sesudah diberikan intervensi meningkat sebesar 0,4533 dan kelompok non perlakuan meningkat sebesar 0,2 sehingga selisihnya sebesar 0,3 . Ada pengaruh konseling gizi terhadap tindakan ibu dalam pemberian MP-ASI sebelum dan sesudah intervensi yang signifikan. Hal ini terlihat dari uji statistik Wilcoxon Signed Ranks Test diperoleh hasil $\mathrm{p}<0.05$ yaitu 0.00 . Ada pengaruh tindakan ibu terhadap peningkatan berat badan balita akibat konseling gizi. Hal ini terlihat dari hasil uji Mann-WhitneyTest diperoleh hasil $\mathrm{p}<0.05$ yaitu $0.01 \mathrm{~S}$ (Nugraha, 2017)

Masa balita adalah masa yang menitikberatkan pada pentingnya perhatian peningkatan pertumbuhan dan perkembangan. Masa balita adalah masaemas ( golden age periode) karna cepatnya pertumbuhan dan perkembangan fisik motorik kasar dan motorik halus anak tersebut (Elizabeth,2006). Seiring dengan proses belajarnya Maka anak banyak bergerak dan melakukan eksplorasi untuk memenuhi rasa ingin taunya, Anak akan berjalan, berlari, bermain, dan bernyanyi, bahkan berfikir. Berat otak anak kurang dari 10 $\%$ dari total berat tubuhnya, namun kebutuhan energinya lebih dari $40 \%$ total energi tubuh Nya untuk mendukung pertumbuhan dan perkembangan otaknya. Juga malnutrisi menyebabkan sekitar setengah dari seluruh kematian anak diseluruh dunia. Secara global, 99 juta anak usia di bawah lima tahun kekurangan berat badan pada tahun 2012. Kecenderungan global dalam provelensi underweight terus menurun, tetapi pada kecepatan lambat. Antara tahun 1990 dan 2012 prevelensi underweight menurun dari $25 \%$ menjadi $15 \%$, yang tetap cukup memenuhi Mllennium Development Goals (MDGs) untuk mengurangi prevelensi tahun 1990-2015'. 
Penyebab mal nutrisi pada masa anak-anak banyak dan komplek. Seagai dijelaskan secara luas dalam kerangka konsel tual UNICF tentang mal nutrisi dengan asupan makanan yang tidak memadai (kebanyakan makanan berkualitas buruk renda kalori dan nutrisi yang penting) dan infeksi sebagai alasan utama yang terkait yaitu mal nutrisi pada masa anak-anak yang diperburuk oleh faktor-faktor seperti status ekonomi,kebersihan,kondisi hidup, pendidikan orang tua dan praktik pemberian makan. Praktik pemberian makan yang buruk dapat merugikan dan berdampak pada kesehatan dan status gizi yang akhirnya mendapat konsukuensi langsung terhadap perkembanga dan fisik pada anak (Hakim, 2016). Tingginya prevelensi gizi kurang dikawatirkan dapat berdampak pada status gizi buruk pada periode selanjutnya. Keadaan gizi akan mempengaruhi tingkat kesehatan dan umur harapan.Dalam studi lain, anak-anak dengan malnutrisi berat yang menerima suplementasi nutrisi dan stimulasi psikososial menunjukkan peningkatan perkembangan mental dan psikomotorik dan penambahan berat badan setelah 6 bulan intervensi. Namun sangat sedikit penelitian yang melibatkan anak berusia $<12$ bulan atau wanita selama kehamilan (Ara, 2019)

\section{KESIMPULAN DAN SARAN}

Hasil pre-tets dan post-test konseling pada kelompok perlakuan menunjukkan meningkat walaupun tidak signifikan, hasil post-test terhadap pemahaman pada pola asuh ibu balita, pada kelompok perlakuan terjadi peningkatan dari 10 responden $(32,6 \%)$ pada saat pretest menjadi 18 responden $(52,4 \%)$ pada saat post-test sedangkan sisanya 17 responden $(47,4 \%)$ masih belum memahami tentang pola asuh ibu balita. Sedangkan presentasi pada kelompok kontrol menunjukkan tidak terjadi perubahan Sebagai tenaga kesehatan dituntut untuk memberikan pelayan dengan baik.untuk itu, diri kita harus selalu membuka diri untuk menerima kritik dan saran. Sebab dengan begitu hubungan dengan pasien bisa semakin dekat dan pemberian intervensi semakin baik sejalan dengan proses untuk selalu ingin belajar.

\section{DAFTAR PUSTAKA}

Ara, G. et al. (2019). Peer Counseling Promotes Appropriate Infant Feeding Practices and Improves Infant Growth and Development in an Urban Slum in Bangladesh: A Community-Based Cluster Randomized Controlled Trial. Current Developments in Nutrition, 3(7), 1-10. https://doi.org/10.1093/cdn/nzz072

Hakim, M. A. (2016). Malnutrition Prevalence and Nutrition Counseling in Developing Countries: A Case Study. International Journal of Nursing and Health Science, $3(3), 19-22$.

K, F. A. (2019). Faktor Determinan Yang Mempengaruhi Terjadinya Gizi Kurang Pada Balita Di Kabupaten Polewali Mandar. J-KESMAS: Jurnal Kesehatan Masyarakat, $\quad 4(2), \quad 91$. https://doi.org/10.35329/jkesmas.v4i2.251

Kesehatan, R. (2013). Penyajian Pokok-Pokok Hasil Riset Kesehatan Dasar 2013.

Khasanah, U. (2014). Program makan dan Anak.

Kusumaningrum, Rinda and Astutik Pudjirahaju. 2018. Konseling gizi terhadap pengetahuan gizi dan sikap ibu, pola makan serta tingkat konsumsi energi dan protein balita gizi kurang. 4(1), 5363.

Kusumaningrum, R., \& Pudjirahaju, A. (2018). Konseling Gizi Terhadap Pengetahuan Gizi Dan Sikap Ibu, Pola Makan Serta Tingkat Konsumsi Energi Dan Protein Balita Gizi Kurang. Jurnal Informasi Kesehatan Indonesia (JIKI), 4(1), 53. https://doi.org/10.31290/jiki.v(4)i(1)y(201 8).page:53-63

Nugraha, et al. (2017). Pengaruh Konseling Gizi Terhadap Tindakan Ibu Dalam Pemberian Mp-Asi Dan Berat Badan Kabupaten Lombok Barat. Jurnal Gizi Prima, 2(2), 137-147.

Purba, lili sari A. and Harahap, K. (2019). HUBUNGAN KESADARAN GIZI KELUARGA DENGAN STATUS GIZI PADA BALITA DI DESA SIDOARJO KECAMATAN JAMBON KABUPATEN PONOROGO. Journal of Chemical Information and Modeling, 53(9), 16891699.

https://doi.org/10.1017/CBO97811074153 24.004

Puspitasari, L. (2015). Pengaruh pendidikan 
kesehatan terhadap perubahan pengetahuan dan sikap ibu dalam upaya menangani balita gizi kurang di desa mancasan sukoharjo. Fakultas Ilmu Kesehatan Universitas Muhammadiyah Surakarta.

Rahayu, et al. (2018a). Pengaruh Konseling Gizi Terhadap Pengetahuan dan Pola Asuh Ibu Balita Gizi Kurang. 5(1), 32-38.

Rahayu, et al. (2018b). Pola Asuh Ibu Balita Gizi Kurang. 5(1), 32-38.

Rahmawati, et al. (2017). PENGARUH KONSELING GIZI DENGAN MEDIA
BOOKLET TERHADAP PENINGKATAN

PENGETAHUAN, SIKAP, DAN TINDAKAN IBU DALAM UPAYA PENCEGAHAN GIZI BURUK BALITA DI WILAYAH KERJA PUSKESMAS PUSWATU KOTA KENDARI TAHUN 2017. 2(6), 1-12.

Yusuf, et al. (2012). Pengaruh Konseling Gizi pada Ibu BATITA Gizi Kurang Terhadap Perubahan Status Gizi BATITA di Wilayah Kerja Puskesmas Dempo Kecamatan Ilir Timur I Kota Palembang Tahun 2012. 